\title{
元井臀子牛見忠藏
}

$1035 \sim 1045$ (1969).

46) 前田 忠, ほか：寄生虫学雑誌, 24 (増刊号) 49 (1975).

47) 松田 肇, ほか：寄生虫学雑誌, 16, 1277 (1967).

48) 松村光博, ほか: 昭和 52 年度日本臨床獣医学会 (小動物・神奈川) 講演要旨 (1977).

49) Magnuson, H. J. \& Raulston, B.D.: Ann. Int. Med., 14, 2199 2209 (1940).

50) McNeill, K. M. \& Hutchison, W. F.: Canine Heartworm Disease, 51 54, Pub. Univ. Florida (1972).

51) 三阪 力，ほか：日獣会誌，24,671 676(1971).

52）野田亮二, 野田周作 : 獣医畜産新報, 100, 28 32 (1952).

53) 大石 勇, 注か：寄生虫学雑誌, 24 (増刊号) 52 (1975).

54) 大石 勇, 泀か：寄生虫学雑誌, 25 (増刊号) 51 (1976).

55) 大石 勇, ほか：日獣会誌, 23, 655 (1970).

56) 大石 勇, ほか：日獣会誌, 13, 252 256 (1960).

57) 大石 勇, ほか：日獣会誌, 17, 603〜608(1964).

58) 大石 勇, 浪か: Small Animal Clinic, 61, 7〜17 (1970).

59 ) 大石 勇; ほか：日獣誌, 34 (学会号) 177〜 178 (1972).

60)大石 勇, ほか：未発表論文 (1976).
61) 大石 勇, 久米清治：日獣会誌，6, 46〜50(1954).

62) 大石 勇, 久米清治 : 日獣会誌, 9, 422 517 (1956).

63) 大石 勇, 注か：日獣会誌, 9, 267〜271 (1956).

64) Otto, G. F. \& Maren, T.H.: J. Parasit., 31 (Supl.) 17 (1945).

65) Отto, G. F. \& Maren, T.H.: Vet. Med., 52, 128 (1947).

66) Otto, G. F. \& Maren, T.H.: Ann. N. Y. Acad. Sci., 50, 39 50 (1948).

67) Rainey, E.F. \& Morgan, H.C.: Canine Heartworm Disease, 76 97, Pub. Univ. Florida (1970).

68）阪野哲也，济：獣医畜産新報，585，24～27 (1973).

69) 佐藤孝慈：寄生虫学雑誌，9，22～31 (1960).

70) 佐藤修二, 堀口佳哉: 共立商事学術資料 (1976).

71) 杉山守男, 汪か：日獣会誌, 19, 420 (1966).

72）武富秋夫, ほか：日獣会誌，23，652 (1970).

73) 富田 勲, ほ力：共立商事学術資料 (1976).

74) 土川 清：共立商事学術資料 (1976).

75) 海野 隆, ほか：第 81 回日獣会 (1976).

76) 若狭芳男, ほか：第 81 回日獣会 (1976).

77) Windmolz, M.: The Merk Index, 9th ed., 405 (1976).

78) Yarborough, J.H., et al.: Small Animal Clinician, i, $151 \sim 152(1961)$.

$$
\begin{gathered}
\text { 牛のいわゆるロボット病の全国の発生状況について } \\
\text { 元井臀子* 牛 見忠 蔵* } \\
\text { (昭和 } 54 \text { 年 } 2 \text { 月 } 16 \text { 日受理) }
\end{gathered}
$$

\section{Incidence of So-called Robot Disease in Cattle in Japan}

Moeko Moto and Chuzo Ushim (National Institute of Animal Health, Yatabe, Ibaraki, 300-21)

\section{SUMMARY}

A nation-wide survey was conducted on so-called robot disease in growing and fattening cattle in Japan. Over a period of 5.5 years about 3,000 cattle were affected with this disease on about 900 farms. They were about $2 \%$ of all the cattle raised on these farms.
They manifested clinical symptoms $4 \sim 9$ months after introduced into these farms, when about $80 \%$ of them weighed $200 \sim 400 \mathrm{~kg}$. These symptoms were curved back, extended and stiffened extremities, extended and deformed hoofs, disturbance of gait, and astasia.

\section{要 約}

最近, 育成牛括よび肥育牛にいわゆるロボット病が発 生しているが, その発生状況については不明な点が多 い.そこで各県の畜産課をつうじて全国調査を行なっ

\footnotetext{
* 農林水産省家畜衛生試験場 (茨城県筑波郡谷田部町
} 観音台3-1-1)
た。

発生が認められた地区は 1 道36県と広範囲にわたり， 昭和, 47 年 1 月から 52 年 6 月までの期間に本病の発生 が認められた農家の延べ戸数は約 900 戸, 発生牛の総数 は約 3,000 頭で, これは発生農家が当時繫養していた牛 の総数に対して約 $2 \%$ であった.

発生農家の半数は農山村で個人経営をして和り，ほと 
牛のいわゆるロボット病の全国の発生状況について

んどの農家が舎飼のみで牛を飼育し，畜舎内の通風，採 光, 排水状況などは良好なものが多かった.

発症牛の種類はホルスタイン系が約 $85 \%$ と王倒的に 多かったが，和牛にも認められた。性別は去勢雄が $76 \%$ と多からたが雄や雌にも少数認められた. 発症牛のらち 約 $80 \%$ が体重 200 400 kg で発症し，導入から発症 までの経過月数は 4〜9カ月であった．その臨床症状は 注とんどの牛が背彎, 開張などの異常姿勢, 四肢の強 直, 蹄の変形, 伸長を呈して和り, 歩行困難, 起立不能 となり著明に削瘦した。

給与飼料内容は育成期は配合飼料とワラが主であり, 肥育期ではこれに加兄て圧ペん麦が主な飼料構成であっ た.

\section{1. は じめに}

最近, 育成牛および肥育牛に前後肢の強拘歩様, 異常 姿勢, 䟱鞘の伸長と変形などの臨床症状を示す疾病（い わゆるロボット病が）が多発して括り，その実態や発生 状況については二，三の報告? 9) があるが，まだ不明な 点が多い，また，その原因などについては目下種々論議 されているところであるが，いずれにしても，本症に対 する原因究明の手がかりとして，わが国に护壮る発生状 況を把握することが必要であると考光全国調査を行なっ た.

\section{2. 調查方法と内容}

調查は畜産局衛生課の協力を得て，各県の畜産課をつ うじて行なった. 調査期間は, 昭和 47 年 1 月から 52 年 6 月末でで, 調査対象はロボット病牛和よびその発生 農家とした。

調査内容は，農家については，飼養している牛の用 途, 飼養総頭数, 経営形態, 飼養形態扣よび 52 年 6 月 までの発生頭数などであった. 調査牛においては四肢の 強拘, 異常姿勢, 蹄鞘の伸長, 変形などの有無を観察 しこれらのらち同時に二つ以上の所見を認めたものを ロボット病として診断した.

発症牛に対する調査は主な臨床症状, 導入時および発 症時の体重と時期など, 給与飼料の種類と 1 頭当たりの 平均給与量について行なった。な和，これらのデータは $x^{2}$ 検定で処理した.

\section{3. 結果}

\section{1）ロボット病の全国発生地域}

いわゆるロボット病の全国発生の分布を図 1 に示し た. 調查に対して解答があったのは40県で, そのうち昭和 47 年から 52 年 6 月の間に発生を認めた県は 1 道 36 県 (北海道, 青森, 岩手, 山形, 宮城, 福島, 神奈川, 千 葉, 茨城, 栃木, 埼玉, 群馬, 新潟, 長野, 静岡, 岐

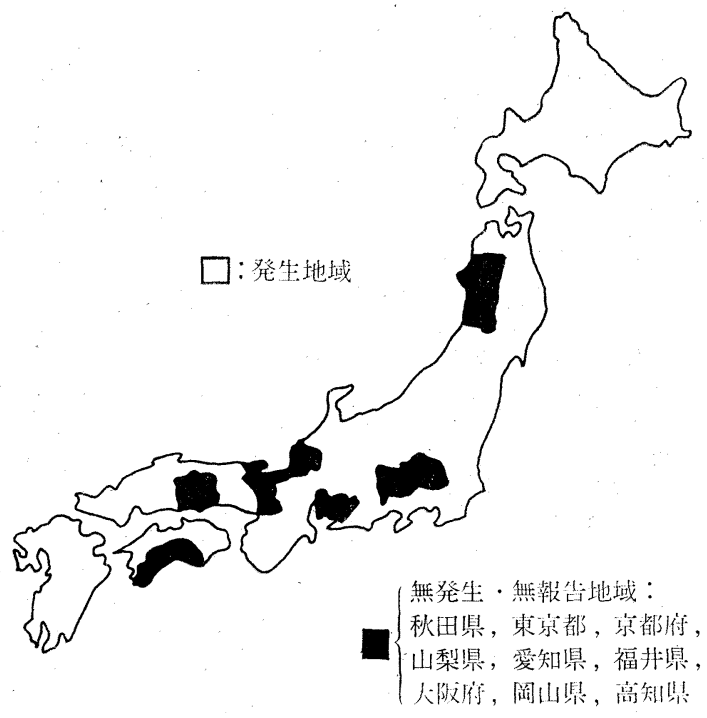

図 1 いわゆるロボット病の全国発生分布図

阜, 三重, 奈良, 滋賀, 和歌山, 兵庫; 石川, 富山, 鳥 取, 島根, 広島, 山口, 香川, 徳島, 愛媛, 福岡, 熊 本, 長崎, 佐賀, 大分, 宮崎, 鹿児島の各道県) の広範 用にわたり，認めなかったのは秋田県，東京都と京都府 であった。

\section{2）全国および各地域の発生状況}

約 6 年間の全国および各地域の発生数を表 1 および図

表 1 牛のいわゆるロボット病の全国発生数

\begin{tabular}{|c|c|c|c|c|}
\hline 地 域 名 & 県数 & $\begin{array}{l}\text { 登生 } \\
\text { 農家数 }\end{array}$ & $\begin{array}{l}\text { 飼養牛 } \\
\text { 総 数 }\end{array}$ & $\begin{array}{l}\text { 発症牛 } \\
\text { 総 }\end{array}$ \\
\hline 北海道 - 東北 & 6 & 190 & 62,836 & $872(1.4)$ \\
\hline 関 東 & 6 & 162 & 17,613 & $377(2.1)$ \\
\hline 中 部 - 北 陸 & 6 & 115 & 12,418 & $302(2.4)$ \\
\hline 畿 & 5 & 70 & 10,552 & $259(2.5)$ \\
\hline 山 陰 - 山 陽 & 4 & 43 & 6,535 & $214(3.4)$ \\
\hline 四国 - 九 州 & 10 & 310 & 31,525 & $893(2.8)$ \\
\hline 国 & 37 & 890 & 141,479 & $917(2.1)$ \\
\hline
\end{tabular}

（） は発症牛総数／飼養牛総数

\begin{tabular}{|c|c|c|c|c|c|c|c|}
\hline \multicolumn{2}{|c|}{$\begin{array}{l}\text { 北海道 } \\
\text { - 東北 }\end{array}$} & & & & & 地㖪名 & 発牛率 \\
\hline * & 関果 & & & & & 山陰・山陽 & 3.3 \\
\hline ※ & ns & 山郘 & · 北阳 & & & 川니月目 · 儿州 & 2.8 \\
\hline ※* & ns & ns & 近㜅 & & & 近䌡 & 2.5 \\
\hline$\because \%$ & \%* & $\because *$ & \% & 山陵 & ·山上陽 & 小胡·北㩐 & 2.4 \\
\hline ※* & ※* & $* *$ & $\%$ & $* \%$ & 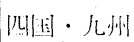 & 関東 & 2.1 \\
\hline
\end{tabular}

図2 各地域に打汀る発生率 
元井搌子牛見忠蔵

表 2 牛のいわゆるロボット病の年次別発生数

\begin{tabular}{|c|c|c|c|c|c|c|}
\hline 地域名／年次 & 47 & 48 & 49 & 50 & 51 & 52 \\
\hline 北海道・東北 & $\begin{array}{l}78 / 6,051 \\
(1.3)\end{array}$ & $\begin{array}{c}102 / 7,766 \\
(1.3)\end{array}$ & $\begin{array}{l}102 / 9,157 \\
(1.1)\end{array}$ & $\begin{array}{c}184 / 14,417 \\
(1.3)\end{array}$ & $\begin{array}{c}261 / 12,821 \\
(2.0)\end{array}$ & $\begin{array}{c}145 / 12,624 \\
(1.2)\end{array}$ \\
\hline 東 & $\begin{array}{c}26 / 905 \\
(2.9)\end{array}$ & $\begin{array}{c}32 / 1,075 \\
(2.9)\end{array}$ & $\begin{array}{l}44 / 1,515 \\
(2.9)\end{array}$ & $\begin{array}{c}65 / 2,466 \\
(2.6)\end{array}$ & $\begin{array}{c}147 / 4,879 \\
(3.0)\end{array}$ & $\begin{array}{c}63 / 6,773 \\
(0.9)\end{array}$ \\
\hline 中 部 - 北 陸 & $\begin{array}{c}25 / 975 \\
(2.6)\end{array}$ & $\begin{array}{l}20 / 1,205 \\
(2.4)\end{array}$ & $\begin{array}{c}63 / 1,992 \\
(3.2)\end{array}$ & $\begin{array}{c}63 / 2,133 \\
(3.0)\end{array}$ & $\begin{array}{c}73 / 3,093 \\
(2.3)\end{array}$ & $\begin{array}{l}49 / 3,020 \\
(1.6)\end{array}$ \\
\hline 畿 & $\begin{array}{l}57 / 2,035 \\
\quad(2.8)\end{array}$ & $\begin{array}{c}64 / 2,170 \\
(3.0)\end{array}$ & $\begin{array}{c}33 / 1,503 \\
(2.2)\end{array}$ & $\begin{array}{c}32 / 1,380 \\
(2.3)\end{array}$ & $\begin{array}{l}44 / 1,410 \\
(3.1)\end{array}$ & $\begin{array}{l}29 / 2,054 \\
(1.4)\end{array}$ \\
\hline 山 陰・山 陽 & $\begin{array}{c}9 / \quad 270 \\
(3.3)\end{array}$ & $\begin{array}{c}23 / \\
(2.7)\end{array}$ & $\begin{array}{c}63 / 1,210 \\
(5.2)\end{array}$ & $28 /(3.3)^{857}$ & $\begin{array}{c}69 / 1,935 \\
(3.6)\end{array}$ & $\begin{array}{l}22 / 1,408 \\
(1.6)\end{array}$ \\
\hline 四 国・九 州 & $\begin{array}{c}44 / \quad 985 \\
(4.5) \\
\end{array}$ & $\begin{array}{c}64 / 985 \\
(6.5)\end{array}$ & $\begin{array}{l}160 / 5,510 \\
\quad(2.9)\end{array}$ & $\begin{array}{c}217 / 6,381 \\
(3.4)\end{array}$ & $\begin{array}{c}307 / 10,215 \\
(3.0)\end{array}$ & $\begin{array}{c}101 / 7,449 \\
(1.4)\end{array}$ \\
\hline 年次 別 総計 & $\begin{array}{c}239 / 11,221 \\
(2.1)\end{array}$ & $\begin{array}{l}314 / 14,056 \\
(2.2)\end{array}$ & $\begin{array}{c}465 / 20,887 \\
(2.2)\end{array}$ & $\begin{array}{c}589 / 27,634 \\
(2.1)\end{array}$ & $\begin{array}{c}901 / 34,353 \\
(2.6)\end{array}$ & $\begin{array}{c}409 / 33,328 \\
(1.2)\end{array}$ \\
\hline
\end{tabular}

数字は発症牛数/飼養牛数（）内数字はその比率を示す

2 に示した. 発生農家の延べ戸数は約 900 戸，発生牛の 総頭数は約 3,000 頭で, これは発生農家が繫養していた 牛の総頭数の約 $2 \%$ に相当していた. 各地域に括ける発 生率をみると, 山陰, 山陽および四国, 九州地方が他の 地方に対して高く, こ扎に比較して北海道, 東北地方が 低い傾向を示した.

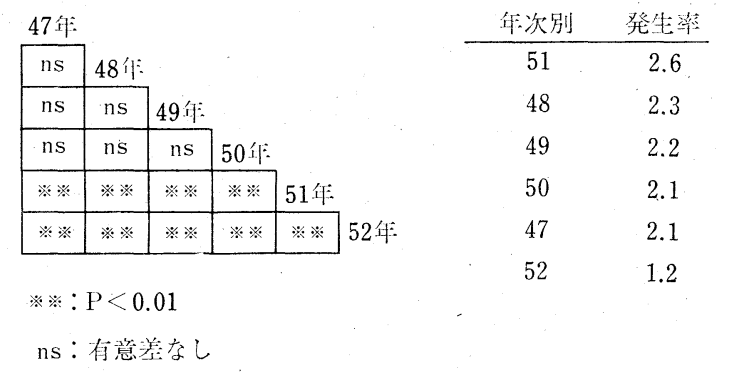

図3 各年次に打ける発生率

\section{3）全国および各地域における年度別の発生状況}

全国の年度別の発生数は表 2 と図 3 に示した. 47年か ら50 年にかけては, 各年度間の発生率に有意差は認め られなかったが，51年は他の年に比べ発生率は高く, 逆 に 52 年は約半年間の調査成績の結果のためか, 発生率 は半減していた. 各地域に拈ける年度別の発生数括よび 各年度に和ける地域別の発生数を表 2 に示した. 各年度 に括ける各地域間の差を検定した結果, 47 年から 51 年 まではロボット病の発生数は北海道・東北地方は他地域 に比べて有意に低かった. いっぽう，47・48 年度は四 国・九州地方が，49年は山陰・山陽地方が有意に高かっ た.しかし50年度以降になると, 各地域間に有意差はほ とんど認められなかった. 47 年から 52 年までの地域別 の発生率の有意差検定の結果は, 北海道・東北地方は51 年度が, 山陰・山陽地方は 49 年度が, 四国・九州地方
は $47 \cdot 48$ 年度が他年度に比べ有意に高かった. しか し，これ以外の地域は各年度間に有意差を認めず，毎年 ほぼ一定の発生率を示した。

\section{4）発生農家における飼養状況}

ロボット病発生農家の飼養環境や状況などについては 表 3 および図 4 ・5 に示した。経営形態としては $78 \%$ が個人経営で最も多く，公共体の経営は少なかった．飼 養環境は都市近郊や山村が少なく，平地農村か農山村が 大部分であった.フリーバーンあるいはペンバーン方式 の舎飼が $80 \%$ と圧倒的に多く，これに運動場や放牧場 などが附属しているものは少なかった，畜舎の床の材質 はコンクリートかアスファルト，運動場は土が多い傾向 がみられた：畜舎の通風, 採光, 排水などは良好であっ た. 発生農家に和ける給水状況は自由給水が制限給水よ り圧倒的に多く, 飲水の種類としては井戸水, 水道水が 多くついで山水などであった.

\section{経学形態}

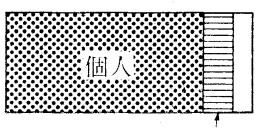

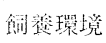

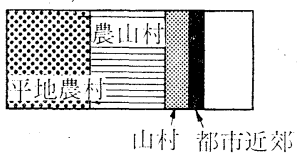

调養形態

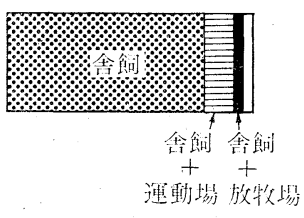

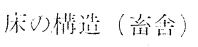

住の㭗造(渾動場)
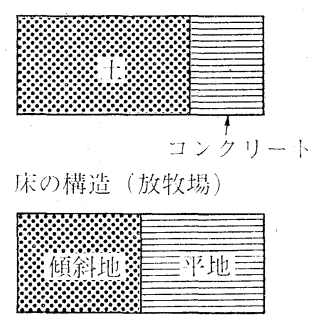

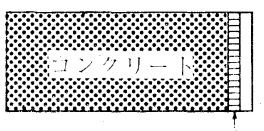

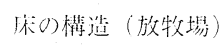

図4 発生農家について 
表 3 ロボット病発生農家についての調査

\begin{tabular}{|c|c|c|c|}
\hline 項 & 目 & & 発現率 $(\%)$ \\
\hline \multirow[t]{6}{*}{ 経 営 形 態 } & 個 & 人 & 78.0 \\
\hline & 協 & 業 & 3.9 \\
\hline & 会 & 社 & 2.4 \\
\hline & 農 & 協 & 4.5 \\
\hline & 公 共 & 体 & 1.3 \\
\hline & 不 & 明 & 0.2 \\
\hline \multirow[t]{5}{*}{ 飼 養 環 境 } & 平地 農 & 村 & 34.0 \\
\hline & 農山 & 村 & 31.0 \\
\hline & 山 才 & 村 & 11.0 \\
\hline & 都 市 近 & 郊 & 5.0 \\
\hline & 不 & 明 & 19.0 \\
\hline \multirow[t]{4}{*}{ 飼 養 形 態 } & & 飼 & 80.2 \\
\hline & \multirow{2}{*}{\multicolumn{2}{|c|}{$\begin{array}{l}\text { 舎飼+運動場 } \\
\text { 舎飼十放牧場 }\end{array}$}} & 13.9 \\
\hline & & & 5.6 \\
\hline & 不 & 明 & 0.3 \\
\hline \multirow[t]{3}{*}{ 休の構造（畜舎） } & \multicolumn{2}{|c|}{$\begin{array}{l}\text { コンクリート } \\
\text { アスファルト }\end{array}$} & 89.1 \\
\hline & 上 & & 7.6 \\
\hline & そ の & 他 & 3.3 \\
\hline \multirow{3}{*}{ （運動場） } & \multirow{2}{*}{\multicolumn{2}{|c|}{$\begin{array}{l}\text { 土 } \\
\text { コンクリート } \\
\text { アスファルト }\end{array}$}} & 69.4 \\
\hline & & & 30.1 \\
\hline & そ & 他 & 0.5 \\
\hline \multirow[t]{3}{*}{ （放牧場） } & 平 & 地 & 49.2 \\
\hline & 傾斜 & 地 & 50.8 \\
\hline & そ の & 他 & 0 \\
\hline \multirow[t]{3}{*}{ 運動場の状 況 } & 乾燥 & 地 & 57.1 \\
\hline & 湿 & 地 & 24.6 \\
\hline & 泥 & 地 & 18.3 \\
\hline \multirow{3}{*}{ 畜舎環境（通風） } & 良 & & 94.9 \\
\hline & 不 & 良 & 3. 9 \\
\hline & 不 & 良 & 1. 2 \\
\hline \multirow[t]{3}{*}{ （採光） } & 良 & & 85.1 \\
\hline & 不 & 良 & 12.1 \\
\hline & 不 & 明 & 2.8 \\
\hline \multirow[t]{3}{*}{ （排水） } & \multicolumn{2}{|l|}{ 良 } & 82.5 \\
\hline & 不 & 良 & 13.3 \\
\hline & 不 & 明 & 4.2 \\
\hline \multirow[t]{3}{*}{ 給 水 状 沿 } & 自 由 給 & 水 & 92.9 \\
\hline & 制 限 & & 4. 0 \\
\hline & 不 & 明 & 3.1 \\
\hline \multirow[t]{6}{*}{ 飲 水 の種 類 } & 水 & 水 & 28.3 \\
\hline & 井 戸 & 水 & 36.6 \\
\hline & 山 & 水 & 24.5 \\
\hline & 川 & 水 & 3.2 \\
\hline & そ & 他 & 1.8 \\
\hline & 不 & 明 & 5.4 \\
\hline
\end{tabular}

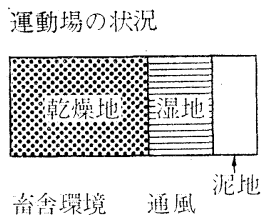

坛等䍗境排水

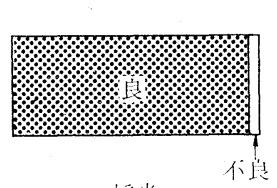

採光:
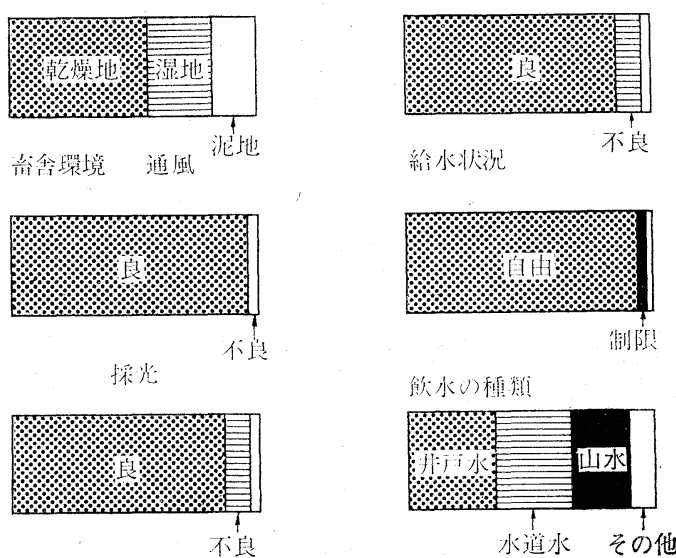

啁 5 発生農家について

\section{5）発症牛についての調查}

発症牛 313 頭についての調查は図 $6 \cdot 7$ に示した. 発 症牛の品種はホル大タイン系が $85 \%$, 和牛は $13 \%$ で, 性別は去勢雄が大部分であり, ついで雌, 雄の順に多か った。これら発症牛の導入時期については年間をと叔し て有意差は認められなかった。これらの牛は体重 200〜 $300 \mathrm{~kg}$ で導入されたものが有意に多く，100 kg以下，100 〜 $200 \mathrm{~kg}$ のもがこれにつぎ, $300 \mathrm{~kg}$ 以上のものは最も 少なかった．発症時に括ける体重は，200kg 以下のもの は少なく, 200〜300 kg, 300〜 400 kg, $400 \mathrm{~kg}$ 以上のもの が，それぞれ約 $30 \%$ を占め，これらの間に有意差は認

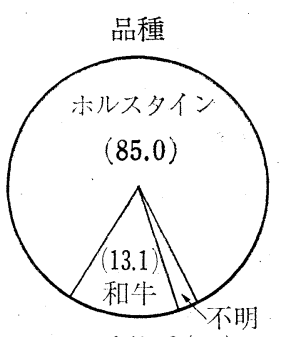

導人時体重 $(\mathrm{kg})$

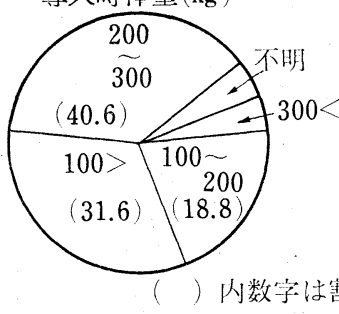

図6 発症牛について

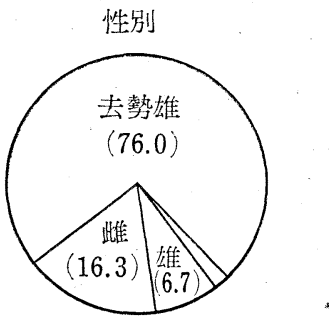

発症時体重 $(\mathrm{kg})$

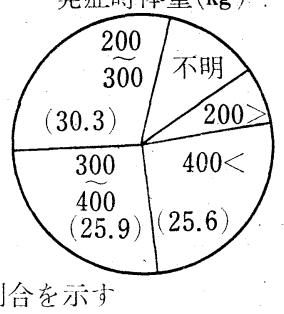


㫕井、臀子子
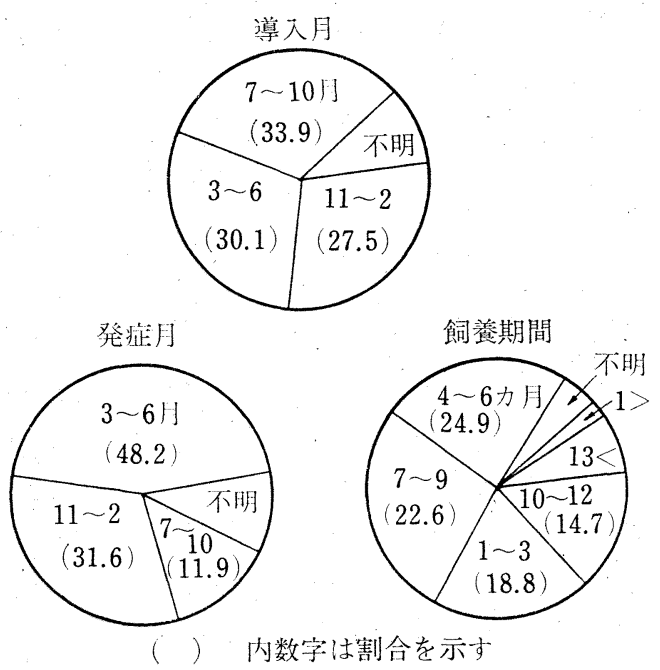

図7発症牛について

められなかった. 発症の季節は $3 \sim 6$ 月が有意に多く, ついで 11〜12 月, 7〜10 月の順であった. 導入から発 症までの飼養月数を及ると導入後 $1 \sim 9$ カ月で発症した あのが多く，1 カ月以下敊よび 13 カ月以上で発症した ものは，きわめて少なかった。

\section{6）発症牛の臨床症状について}

発症牛の主な臨床症状と発症頭数を表 4 亿示した. 四 肢部の強拘はすべての牛認められた. なかでも前肢の み誌められたものが約 $80 \%$ で前後肢あるいは後肢の及

表 4 口ボッ卜病牛の主な臨床症状

\begin{tabular}{|c|c|c|c|c|c|c|}
\hline 臨床症状 & 盚教 & $\%$ & \multicolumn{2}{|c|}{ 臨床症状 } & 発生 & $\%$ \\
\hline 前 肢 強 拘 & 245 & 78.3 & \multicolumn{2}{|c|}{ 関 節 尰 脹 } & 63 & 20.1 \\
\hline \multirow{2}{*}{$\begin{array}{l}\text { 前後肢強拘 } \\
\text { 後 肢 強 拘 }\end{array}$} & 15 & 4.8 & な & し & 250 & 79. 9 \\
\hline & 53 & 16.9 & \multicolumn{2}{|c|}{ 蹄 伸 長 } & 243 & 77.6 \\
\hline 姿勢 異 状 & 279 & 89.1 & \multirow{2}{*}{\multicolumn{2}{|c|}{$\begin{array}{l}\text { 前 蹄 } \\
\text { 前 後蹄 }\end{array}$}} & 196 & 62.6 \\
\hline \multirow{4}{*}{$\begin{array}{cc}\text { 開脚 } & \text { 背 弯 } \\
\text { 開 } & \text { 脚 } \\
\text { 背 } & \text { 弯 } \\
\text { な } & \text { 乙 } \\
\end{array}$} & 131 & 41.9 & & & 44 & 14.1 \\
\hline & 93 & 29.7 & .後 & 蹱 & 3 & 0.9 \\
\hline & 55 & 17. 6 & な & ᄂ & 70 & 22.4 \\
\hline & 34 & 10.9 & \multicolumn{2}{|c|}{ 形態異状 } & 202 & 64.5 \\
\hline 跛 & 213 & 68.1 & \multirow{4}{*}{$\begin{array}{l}\text { 前 } \\
\text { 前 後 } \\
\text { 後 } \\
\text { な }\end{array}$} & 蹄 & 165 & 52.7 \\
\hline な & 100 & 31.9 & & 嗳 & 34 & 10. 9 \\
\hline 歩-行 困 難 & 175 & 55.9 & & 蹄 & 3 & 0.9 \\
\hline な & 138 & 44.1 & & ᄂ & 111 & 35.5 \\
\hline 起 立 不能 & 21 & 6.7 & 圧 & 痛 & 43 & 13. 7 \\
\hline な & 292 & 93.3 & な & ᄂ & 270 & 86.3 \\
\hline \multirow{2}{*}{\multicolumn{3}{|c|}{$\begin{array}{l}\text { 発症牛 } 313 \text { 頭についての臨 } \\
\text { 床症状 }\end{array}$}} & 削 & 瘦 & 111 & 35.5 \\
\hline & & & な & ᄂ & 202 & 64.5 \\
\hline
\end{tabular}

の強拘は少なかった．異常姿勢の認められたものは約 90\%で，そのうち開脚捛よび背彎姿勢の合併を示した ものが約 40\%, 開脚姿勢のみが 30\%, 背彎姿勢の及が 約 $20 \%$ であった. 跛行を示したるのが約70\%, 歩行困 難なるのは約 $56 \%$ であったが, 関節の畽脹はそれ汪ど 認められず，起立不能にまで陷ったものは約 $7 \%$ であっ た. 発症牛の約 $80 \%$ に蹄鞘ののびが認められたが, な かでも前肢の蹄鞘ののびが注とんどで前後肢部あるいは 後肢の蹄鞘のみが伸長していたものは少なかった. 蹄䩗 の形態が異常を示したのは約 65\% で伸長と同様に前肢 餏鞘の形態異常が多かった. そして発症牛の $35 \%$ に当 たる約 110 頭に削馊を認めた。

\section{7) 飼料給与状況と種類}

発症牛に対する飼料の給与方法や種類などについては 育成期と肥育期に分けて調査し，図10 と表 5 と示した。 飼料の給与方法は育成期も肥育期も制限給餌より不断給 慨が多く，とくに肥育期では育成期に比べて不断給䭒農 家が有意に多かった. 図 8 亿示した給与飼料の内容は, 各県の発症農家の給与している飼料を 80〜100\%，50〜 80\%未満，30～50\%未満特よび 10〜30\% 未満にそれぞ れ分けて表現した。市成期では北海道のよらにワラの代 わりに牧草乾草を給与しているところを除いては，ほと んどの県で配合飼料とワラが主な飼料構成であり，それ 飞少量の圧ぺん麦, 乾草, フマスなどが附加されてい た. 給与量は各県さまざまであるが, 配合飼料が $5.3 \pm$ $2.2 \mathrm{~kg}$ ， ワラが $1.7 \pm 0.7 \mathrm{~kg}$ で 1 頭当たりの給与総量は $7.2 \pm 2.1 \mathrm{~kg}$ であった. 肥育期では配合飼料とワラに加 壳て圧ぺん麦が主な飼料構成であり, その他にフスマ, 青草, 乾草などが給与されていた. 給与量は配合飼料 6.1 $\pm 1.3 \mathrm{~kg}$ ，圧ぺん麦が $-2.5 \pm 0.8 \mathrm{~kg}$ ，ワラが $2.5 \pm 1.1 \mathrm{~kg}$ で給与総量は $11.4 \pm 2.2 \mathrm{~kg}$ であった。

\section{表 5 主な飼料の給与量}

\begin{tabular}{|c|c|c|c|c|}
\hline & 育 & 期 & $(\mathrm{kg})$ & \\
\hline 制限／不断 & 配 合 & $\nabla$ & ラ & 総 量 \\
\hline \multirow[t]{2}{*}{$30 / 51$} & \multicolumn{2}{|c|}{$5.3 \pm 2.2$} & $1.7 \pm 0.65$ & $7.2 \pm 2.1$ \\
\hline & 肥 & 期 & (kg) & \\
\hline 制限／不断 & 配 合 & 压ぺん麦 & $7 \quad \overline{7}$ & 総 量 \\
\hline $45 / 152$ & $6.1 \pm 1.3$ & $2.5 \pm 0.8$ & $2.5 \pm 1.1$ & $1 \quad 11.4 \pm 2.2$ \\
\hline
\end{tabular}

\section{考察}

臨床所見から「ッッパリ病」「木馬病」「キリン病」, 「前肢強拘症」「「ロボット病」などとさまざまに称されて いる，いわゆる育成拉よび肥育牛に発生する四肢の強拘 や異常姿勢, 蹄鞘角質の伸長, 変形などを主徵とする疾 病については比較的多くの報告がある. 同様な臨床症状 のものについてその病理学的所見から蹄葉炎であるとい 
牛のいわゆるロボット病の全国の発生状況について

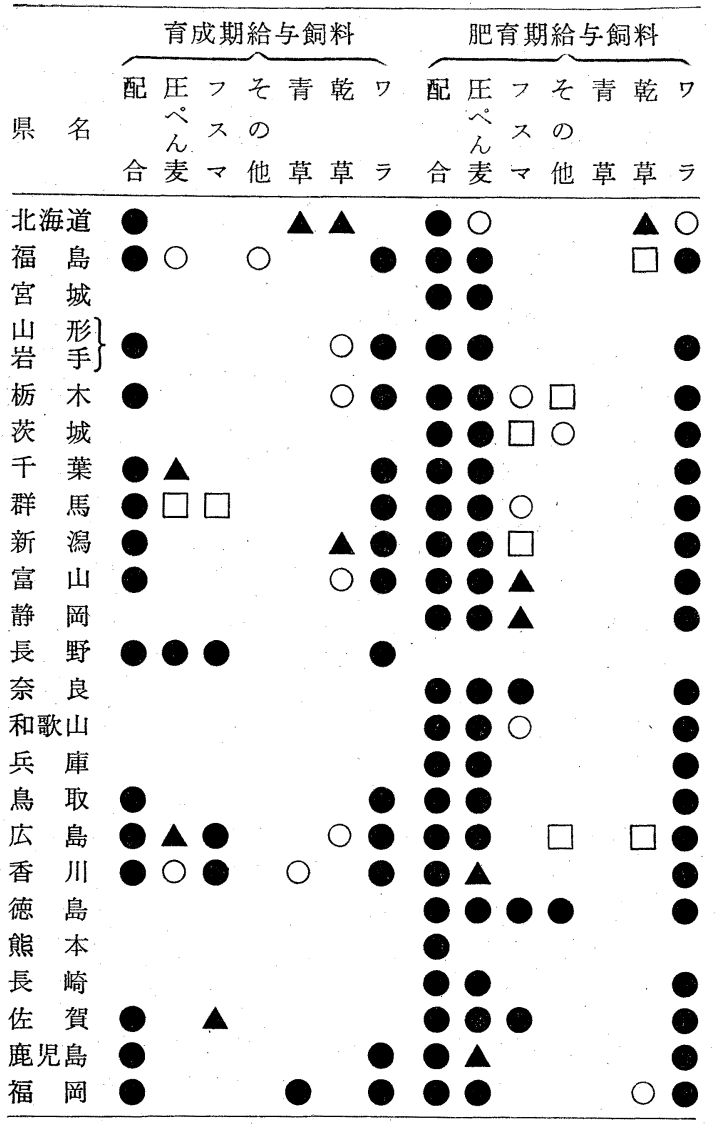

: 農家の80〜100\%が給与している飼料 ○:50〜 $80 \%$ 未満 $\boldsymbol{\Delta}: 30 \sim 50 \%$ 未満 $\square: 10 \sim 30 \%$ 未満

図 8 飼料給与状況々種類

う報告もある. 牛の蹄葉炎については 1963 年にNILSSON 1) がその臨床的，形態的な所見について詳細に述べてい る.

蹄葉炎は歴史的には馬に頻発した疾病であったが，今 日ではむしろ若齢肥育牛にとって重要な病気であるとい われている.この原因については多くの人々によってさ まざまに論議されているが，いまだに明らかにされてい ない，本病についての地域的な調査報告は二，三ある が，全国的な調查はいまだになされていない。この調査 は昭和 47 年から 52 年 6 月までの口ボット病の発生と その状況について調査したわけであるが，その間の全国

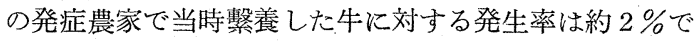
あった. 地域別では北海道・東北地方が飼養牛総数が多 いためか発生率は逆に低く，全国的には山陰・山陽，四 国・九州などの西日本に高い傾向を示した．各年次での 全国発症率にはあまり差が認められなかったことから， 本病は毎年比較的均一に発症する疾病と思われるが， 52 年は 6 月までの調査なので例年の約半分の発症率であっ た.
発生農家の調査の結果，いわゆる追い込及方式の舎飼 が多く，しかも床材はコンクリートかあるいはアスファ ルトが圧倒的に多かった。 WooD ${ }^{11)}$ は牛の蹄葉炎の発生 要因の一つとして堅い休面での歩行や長期間の起立によ り足に対する体重の過度な負荷をあげている．また梅本 $ら^{10)}$ は乳用雄犢の四肢にかかる負重は後肢より前肢にか かる比率が大きいと報告している. 今回の調査でも，こ の体重の負荷のせいか発症牛の多くに後肢よりも前肢の 及に強拘や蹄の伸長, 変形を強く認めた。 今回は臨床症 状のみで本病を診断しているため，脚部の他の疾患も混 っている可能性が考觉られるが，関節部に腫脹などが発 現した割合が低かったことなどから関節炎の併発は比較 的少ないるのと思われる. 発症牛のなかには食欲がある にもかかわらず，蹄部の疾患で採食困難となるためか， あるいは二次的な物質代謝障害によるのかの理由で，全 身的な削瘦を認めたものがあった．そしてこの数は発症 牛の約 $1 / 3$ にものぼり，その経済的損失はかなり大きい あのと推察される. 本病は, その飼育頭数が多いためか 乳用雄子牛の去勢雄に発生が多いといわれていたが，調 查の結果では褐毛・黒毛などの和牛や，さらに雌や無去 勢雄にもかなり発症を認めた。いっぽう，欧米ではMA$\mathrm{CLEAN}^{5)}$ がフリージアン種, エイアシアー種, ガンジー 種牛などにも蹄葉炎の発症を認めたと報告して物り, $\mathrm{MORROW}^{6)}$ ら, NILSSON${ }^{1,2)}$ は, 乳用牛の蹄葉炎発症は分 娩亡密接な関係があると述べている.わが国に打いても 当然・育成拉よび肥育中の肉用牛に限らず，搾乳牛など 他用途の牛での発生が予想される. 素牛の導入時期がさ まざまであるにもかかわらず，導入時の体重が $100 \mathrm{~kg}$ 以 下および 200〜 $300 \mathrm{~kg}$ と二つの時期に集中しているため か, 発症時期が $3 \sim 6$ 月と $11 \sim 2$ 月に多かった。 これは 其田ら ${ }^{7)}$ の北海道での報告や静岡県三ケ日町の 梅本ら ${ }^{9}$ の報告と一致している. また発症時の体重についてもこ れらの報告とほぼ一致していた.

Morrow $^{6)}$ ஓ NILSSON ${ }^{2)}$, MACLEAN $^{42}$ らは本病の根 本的な原因として不適当な飼料給与を主張して挆り，か れらの考察によると，若い牛に高蛋白の穀物飼料を高割 合に給与することにより，第一胃内に打ける $\mathrm{pH}$ の変化 特よび蛋白質の代謝異常などによりヒスタミンが増生さ れ，その結果，この物質の起炎作用により，䟱葉部の血 管拡張や充血を来たすのであろらと述べている：さらに 搾乳牛の場合はさぬざまな種類の飼料で注意樑く飼養さ れて打り，ルーメン内でヒスタミンが急激に生成, 増加 されないため蹄葉炎の発生が肥育牛に比べて少ないので あろうと考察している. いずれにしても，飼料の種類， 給与量, 給与方法などが本病の強力な発生要因の一つで あると指摘している. 今回の調査から，その飼料構成は 単純で, 配合飼料とワラとさらに圧ペん麦が主な構成で あった．給与方法としては不断給饂が多いため，1頭当 
島田保昭

たりの 1 日の給与量を正確に算出するのは困難である が，ともかくその平均值を計算すると前述のような数值 となった. この值をもとにして, 体重 $300 \mathrm{~kg}$ で 1 日の増 体量が $1 \mathrm{~kg}$ とした場合の乳用雄去勢牛の 1 頭当たりの 1 日平均給与率を計算してみると日本飼料標準 ${ }^{3)}$ のT D N 約145\%，D C P約135\%となった．これは前述の飼料構 成と給与量から求めた数値なのであくまでも概算である が，現実にはさらにこれを上迴ると思われる，MORROW 6) は本症予防はあくまでも適切な飼料給与にあり, 治療 としては高蛋白飼料の減量が最も効果的であり，ルーメ ンに負担を与えるよらな給与方法は絶対避けるべきであ ると強調している.

以上のことから牛のいわゆるロボット病はもはや若柃 肥育牛を主体とした全国的な疾病であり，その経済的な 損失を防止する意味からも早急に対策を講ずる必要があ ると思われる。

最後にこの調查において多大な協力を下さった，各県 の畜産課执よび調查担当者，そして畜産局衛生課の担当
各位に深謝する。

$$
\text { 参 考 文 献 }
$$

1) Nilsson, S. A.: Acta Vet. Scad., 4 Supp 1, 1 287 (1963).

2) Nilsson, S. A.: Nordisk Vet., 16 Supp 1, 276 283 (1964).

3）農林水産技術会議事務局編 : 日本飼養標準, 肉用 牛, 19 24, 中央畜産会 (1975).

4) MaClean, C. W.: Vet. Rec., 77, 662 672(1965).

5) MaClean, C. W.: Vet. Rec., 78, 223 231(1966).

6) Morrow, D.A.: Vet. Med., 61, 138 146 (1966).

7) 其田三夫, 沼田芳明, 高橋清志, 小谷忠生, 小岩 政照, 千葉好夫 : 第 80 回日本獣医学会 講 演 要旨 (1975).

8）其田三夫：酪農事情，37，32～36 (1977).

9) 梅本弘明, 名倉憲行, 八木達弥: 家畜診療, No. 157, 15 17 (1976).

10）梅本弘明, 石田 寛, 浜崎英正, 多川政弘, 黒川 和雄 : 第 84 回日本獣医学会講演要旨 (1977).

11) Wood, C.: Vet. Rec., 72, 1220 1223 (1960).

\title{
牛 の脂肪壊死症に関する研究
}

IV. 脂肪壊死症牛の脂肪組織の生化学的所見について

\author{
島 甶 保 昭*
}

（昭和 54 年 1 月 19 日受理）

Studies on Adiponecrosis in Cattle IV. Biochemical Findings of Adipose Tissue of Fatally Affected Cattle Yasuaki Shimada

(Animal Husbandry Experiment Station, Prefecture of Hyogo, Himeji 670)

\section{SUMMARY}

Lipids occupied about $50 \sim 60 \%$ of the necrotic adipose tissue, while it did about $90 \%$ in the normal one. Moisture occupied more than $30 \%$ of the necrotic adipose tissue, while it did less than $15 \%$ of the normal one. Crude nitrogen and crude ash of the former were $2 \sim 3$ times as much as those of the latter. $\mathrm{Ca}, \mathrm{Mg}, \mathrm{P}, \mathrm{Na}$, and $\mathrm{K}$ increased, but the saponification value decreased in the necrotic tissue.

\section{1. 緒論}

牛における脂肪壊死症は，蓄積された腹腔内の脂肪組 織が壊死を起こし，その壊死脂肪細胞内に結晶物質が存 在している ${ }^{19)}$ が，これと同様の組織学的所見を示するの にヒトの新生児に希にみられる新生児皮下脂肪壊死症

* 兵庫県畜産試験場 (兵庫県姫路市上大野)
No acid value exhibited big changes in this tissue.

More fat of high degree of saturation was accumulated in the necrotic than in the normal adipose tissue.

TG occupied more than $98 \%$ of the lipids in the adipose tissue, regardless of necrotic or normal condition, of cattle which died of adiponecrosis. In the necrotic adipose tissue, Chl increased a little, but FFA or PL showed no remarkable changes. このヒト新生児の脂肪壊死症の発生機序については, 食 物の役割が強調されている ${ }^{17)}$ ものの，牛に特ける本症と 同様, 現在なお明らかな成因は究明されていない。

しかしながら，牛とヒトの壊死脂肪組織に同じ病理所 見のみられることは, その発生機序にも共通したものが 存在するのではないかと思われ，これら両者の脂肪組織 